\title{
Notes on a Possible Application of the Notion of Assimilation in History
}

\author{
Giuseppe lurato* (D) \\ Ministry of Education, Italy
}

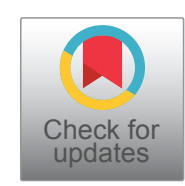

\begin{abstract}
In this brief note, we stand out a possible application of the historical anthropology notion of assimilation to history, with a particular attention to some decolonization aspects and other socio-anthropological phenomena.
\end{abstract}

In cultural anthropology, sociology and social psychology, assimilation is a dynamical process, mainly having a unilateral direction, springing out from the acculturative contact between different cultures, in which a subordinated group is absorbed by the dominant one (acculturation). This process is alternative to the cultural fusion, which is a reciprocal and a bilateral or a two-way process, as well as closely related to the concept of deculturation. This latter entails a rejection (spontaneous or forced) of an original, primary culture (the native one) - due to the coming of an acculturative contact by acculturation - which is so replaced by a new (alien) culture [1-3].

Nevertheless, the forced assimilation of the culture of a dominant group by a dominated one, may lead to violent and aggressive behaviours; furthermore, such a change of cultural paradigms should not be considered ethnocentristically ${ }^{b}$ as the outcome of a kind of inert transplant-connection of a new (alien) culture into the old (native) one, but rather as a dynamical and interactive intercultural process in which dialectically persist both these cultures, the native and the alien one, which react differently to such an acculturation impact according to a ratio belonging along a continuum range (whose one extreme is the segregation) of different levels of reciprocal integration and pluralism [1-3].

Acculturation generally is a dynamical process of cultural change which comes from the contact of two different, autonomous cultures, previously separated of each other but that, after this contact, undergo to modifications and transformations of the own specific and peculiar socio-cultural

aThere hold many possible meanings of the term assimilation, in the widest context of socio-humanities disciplines. We refer to the socio-cultural meaning of the term.

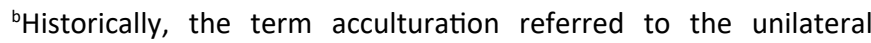
influence of western cultural patterns on the so-called primitive populations most of which were subject to colonization phenomena by western civility, which was considered higher with respect to those of primitive peoples (ethnocentrism). patterns just because of such a cultural interaction. This interactive process is diachronic and has a multiform fashion, as well as dependent on the socio-historical, socio-economical and socio-cultural conditions in which it takes place. The cultural models in reciprocal interaction undergo both to certain changes and modifications due to the contact of each pattern with the other, in a complex and plastic bilateral way which comprehends syncretisms, fusions, remodellings, reinterpretations, rehashes, reformulations, etc., acting in dependence on the degree of adaptation of the predominant pattern to the typical traits of the native one $[1,2,4]$.

From an historical standpoint, acculturation has been taken into consideration by anthropologists only at the beginnings of $20^{\text {th }}$ century, mainly in the United States (in relation to the problems of integration of American Indians and other minorities [5-8]) and in the United Kingdom (in regard to certain questions related to the control of the dominated peoples inside its colonial empire $[3,9])$. The term refers to those complex mechanisms of socio-cultural contact with which a certain social group assimilates, or is undergone to, the cultural elements of another social group. It was just after that Western societies went out of colonial period, that these same studied those societies which had been colonized by them. From these studies, it was emerged that acculturation has remarkable relationships with history, so it is a concept of historical anthropology [10,11].

History of anthropology is closely related to European colonization for many aspects. Recently, anthropologists re-

*Corresponding author: Giuseppe lurato, Ministry of Education, Italy

Accepted: December 07, 2020

Published online: December 09, 2020

Citation: lurato G (2020) Notes on a Possible Application of the Notion of Assimilation in History. Insights Anthropol 4(2):306308

Copyright: (c) 2020 lurato G. This is an open-access article distributed under the terms of the Creative Commons Attribution License, which permits unrestricted use, distribution, and reproduction in any medium, provided the original author and source are credited.
SCHOLARS.DIRECT 
appraise the colonization phenomena, putting it between the permanence of precolonial setting and the pregnancy of the new situations due to colonial experience; they also ask whether colonization has been an historical breaking or a simple historical interval $[7,12]$. In particular, acculturation also regards that typical process of colonization phenomena in which the behaviour of the dominants (just who is in real and personal contact with the subdued population) is often assimilated by dominated peoples, with the possibility of leaving in the background the influence of the dominant society (which may also turn out quite far - geographically - from the dominated one, like in the case of the British domination of India) whom dominants belong. Then, among the most prominent phenomena of acculturation are the wars and the colonization processes $[2,13]$.

Anyway, the acculturation mechanisms run at either the collective level - on the various social systems - and the individual level - on the personality of each single member of dominated group. This last aspect may be formalized better within the framework of symbolic interactionism, if one takes onto account the fundamental notions of primal and secondary socialization process according to $[14,15]$ and their possible relationships with the notions of generalized other [16] through which external society is acquired by each one of its members, so structuring her or his personality through the own self $[2,17,18]$.

The social psychology implications of the contact between different cultures in the interplay in-group/out-group, have been treated by cross-cultural psychology [2,17-20]. In that socio-cultural processes have mainly an unconscious nature [21-23], according to Freudian and Jungian psychoanalysis, acculturation and assimilation might be explained through the defence mechanisms of psychoanalysis, among which are projection, introjection and identification $[1,8,24]$. In social psychology, the predominant pattern of acculturation is the so-called bidimensional model of John W. Berry, in which assimilation is a possible strategy of acculturation, from the in-group perspective, out of four possible strategies of acculturation, i.e., integration, assimilation, separation, and marginality; there also holds the so-called interactive model of acculturation based on five main strategies, i.e., integration, assimilation, segregation, exclusion, and individualism $[17,18,25,26]$.

Moreover, cross-cultural psychology speaks also of psychological acculturation to denote those notable changes, immediate or deferred in time, that an individual undergoes in contact with other cultural patterns which are quite different from the own one. Such a level distinction between group and psychological acculturation is important and useful to understand better the whole influence of different cultural patterns from either the individual and the collective standpoint. Cross-cultural psychology has pointed out the constancy in time of the crucial relation psychological behaviour-cultural patterns; the change degree of the former with respect to the latter, depends on the strategy of acculturation which prevails: for instance, assimilation is the strategy which entails the most intense psychological change in the personal behaviour of an individual, along the widest temporal range.
Finally, acculturation also entails psychological stress called stress of acculturation $[17,18]$.

From an historical standpoint, many socio-cultural aspects of a certain social group which have been in contact with non-native cultural patterns, like in colonization processes, might be explained just in term of acculturation with which, along the course of history, dominated people acquire, by (mainly forced) assimilation, certain social-cultural patterns, schemas or aspects of dominant group, according to a socio-anthropological mechanism similar or analogous to the social incorporation of some different new habitus in the sense of Pierre Bourdieu, with respect to the ones provided by the nearest socio-cultural growth environment [15]. In this context, many socio-cultural aspects of dominated people, still present or persistent after that decolonization has taken place (that is, after dominant people has gone away), might be explained as effects of the previous assimilation of schemas and behaviours of the socio-cultural pattern kept by dominants during their contact with dominated people. Such a persistence, indeed, is a typical feature of many decolonization phenomena $[13,27]$.

For instance, as a possible case-study, the principal socio-cultural features of the main criminal organizations of south Italy (i.e., camorra, 'ndrangheta, and mafia), above all their policies, may be brought back to assimilation by autochthonous of typical schemas, rules and behavioural conducts of the previous dominators which have raged for many centuries just in south Italy, with a very oppressive domination. This is in agreement with what Marc-Henri Piault claimed since 1980s about the influence of colonization in history $[7,12]$, that is to say, it may be considered as a possible casestudy confirming his remarkable ideas [28-30].

\section{Conflict of Interests}

The author declares that there is no conflict of interest.

\section{References}

1. Galimberti U (2018) Dizionario di psicologia, psichiatria, psicoanalisi, neuroscienze. Feltrinelli, Milano.

2. Gallino L (2014) Dizionario di sociologia. UTET-De Agostini, Torino-Novara.

3. Malinowski B (1945) The dynamics of culture change. an inquiry to race relations in Africa. Yale University Press, New Haven (CT).

4. Fabietti U, Remotti F (1997) Dizionario di antropologia. etnologia, antropologia culturale, antropologia sociale. Zanichelli, Bologna.

5. Herskovits MJ (1938) Acculturation. the study of culture contact. JJ Augustin Publisher, New York.

6. Linton R (1940) Acculturation in seven American Indians tribes. Appleton Century Publisher, New York.

7. Piault MH (sous la direction de) (1987) La colonisation: Rupture ou parenthèse? Éditions L'Harmattan.

8. Pieri PF (2005) Dizionario junghiano. Edizione ridotta. Bollati Boringhieri, Torino.

9. Mair L (1939) Methods of study of cultures contact in Africa. Oxford University Press, London. 
10. Bonte P, Izard M (sous la direction de) (1991) Dictionnaire de l'ethnologie et de l'anthropologie. PUF, Paris.

11. Kilani M (2009) Anthropologie. Du local au global. Éditions Armand Colin, Paris.

12. Piault MH (1985) La colonisation: Pour une nouvelle appréciation. Cahiers Orstom. Séries Sciences Humaines 11: 5-12.

13. Droz B (2006) Histoire de la décolonisation au XXe siècle. Éditions du Seuil, Paris.

14. Berger PL, Luckmann T (1966) The social construction of reality. A treatise in the sociology of knowledge. Anchor Books, New York.

15. Dubar C (2000) La socialisation. Construction des identités sociales et professionnells. Éditions Armand Colin/HER Éditeur, Paris.

16. Griswold W (2004) Cultures and societies in a changing world. Sage Publications, Inc., London.

17. Berry JW (2019) Acculturation. A personal journey across cultures. Cambridge University Press, Cambridge, UK.

18. Berry JW, Poortinga YH, Segall MH, et al. (1992) Cross-cultural psychology. Research and applications. Cambridge University Press, Cambridge, UK.

19. Anolli L (2004) Psicologia della cultura. il Mulino, Bologna.

20. Inghilleri P (a cura di) (2009) Psicologia culturale. Raffaello Cortina Editore, Milano.
21. Contarello A, Mazzara BM (2002) Le dimensioni sociali dei processi psicologici. Editori Laterza, Roma-Bari.

22. Cuche D (2004) La notion de culture dans les sciences sociales. Éditions La Découverte, Paris.

23. Moscovici S (1993) The Return of the Unconscious. Social Research 60: 39-93.

24. Mecacci L (2012) Dizionario della Scienze psicologiche. Zanichelli, Bologna.

25. Mazzara BM (2007) Prospettive di psicologia culturale. Modelli teorici e contesti d'azione. Carocci editore, Roma.

26. Villano P (2016) Psicologia sociale. Dalla teoria alla pratica. il Mulino, Bologna.

27. Kennedy D (2016) Decolonization. A very short introduction. Cambridge University Press, Cambridge, UK.

28. Iurato G (2015) Rigidity of the generalized other, narrowness of the otherness and demodernization, in the framework of symbolic interactionism. Preprint HAL Archive-ouvertes: hal01167165, version 5 .

29. Redfield R, Linton R, Herskovits M (1936) A memorandum for the study of acculturation. American Anthropologist 38: 149-152.

30. Spicer EH (1961) Perspectives in American Indian culture change. The University of Chicago Press, Chicago and London.

DOI: $10.36959 / 763 / 517$

Copyright: (C) 2020 lurato G. This is an open-access article distributed under the terms of the Creative Commons Attribution License, which permits unrestricted use, distribution, and reproduction in any medium, provided the original author and source are credited. 